\title{
Aplikasi Remote Sensing dan Geographics Information System untuk Menunjang Database LP2B dan Agrowisata di Subak Sembung Kecamatan Denpasar Utara
}

\section{IMAS CAHYANINGTIYAS ${ }^{1}$, INDAYATI LANYA ${ }^{1 *}$, DAN NI MADE TRIGUNASIH ${ }^{2}$}

Program Studi Agroekoteknologi, Fakultas Pertanian, Universitas Udayana

J1. PB. Sudirman Denpasar 80231 Bali

${ }^{*}$ E-mail: indahnet@yahoo.com

\begin{abstract}
The Application of Remote Sensing and Geographics Information System for database SLA and Agrotourism in Subak Sembung, North Denpasar District. The Regional Spatial Plan (SP) of Denpasar City has designated Subak Sembung as an Agroecotourism Area. Subak Sembung is highly recommended as Sustainable Food Agriculture (SFAL). The determination of the SFAL area requires a geospatial-based agricultural land resource database. The goal is to compile a remote sensing-based SFAL database and Geographical Information System (GIS). Methods of visual analysis of satellite images, field surveys, thematic mapping, and land ownership as well as evaluation of existing agro-ecotourism conditions, especially Sapta Pesona. The conclusion of this study: the Subak Sembung resource potential database (land resources ( LR), artificial resources ( AR), Agricultural Resources, (AgR), Human Resources (HR) and land ownership) is classified as good, equipped with a geospatial-based thematic map of wetland ownership, worthy of being designated as SFAL. Owner farmers $57.24 \%$, cultivators $42.76 \%$. The average age of farmers is 52 years, with elementary school education. The potential of agro-tourism destinations is good, there are two entrances to the jogging tract from the main road, industry, promotion and institutions that still need to be improved to increase the attractiveness of agro-tourism.
\end{abstract}

Keywords: Database, Agrotourism, Ownership of Rice Fields

\section{PENDAHULUAN}

Bali merupakan tujuan wisata dunia, berdampak positif terhadap ekonomi, namun negatif terhadap keberadaan lahan pertanian dan lingkungan. Konversi lahan sawah subak ke non-pertanian berdampak pada berkurangnya persediaan pangan. Pengendalian alih fungsi lahan sawah sebagai program strategis nasional ditegaskan dalam Peraturan Presiden No 59 tahun 2019 (Peraturan Presiden Republik Indonesia, 2019) untuk mempercepat 


\section{IMAS CAHYANINGTIYAS et al. Aplikasi Remote Sensing dan Geographics...}

penetapan lahan sawah yang dilindungi sesuai dengan Undang-Undang (UU) No 41 tahun 2009 (Undang-Undang Republik Indonesia, 2009) tentang Perlindungan Lahan Pertanian Pangan Berkelanjutan (LP2B) yang mengharuskan setiap Pemerintah Daerah (Pemda) membuat Peraturan Daerah (Perda) tentang LP2B yang dilengkapi dengan peta dan database (Peraturan Pemerintah Republik Indonesia, 2012). Peraturan Menteri Agraria dan Tata Ruang/Kepala Badan Pertanahan Nasional (ATR/BPN) No. 19 tahun 2019 mengamanatkan.

Perlindungan lahan sawah subak telah dilakukan oleh Pemda Kota Denpasar dengan menetapkan sebagian besar persawahan di bagian hulu ditetapkan sebagai Ruang Terbuka Hijau Kota (RTHK) (Pemerintah Kota Denpasar, 2011). Subak Sembung selain sebagai RTHK, juga ditetapkan sebagai kawasan agroekowisata. Implementasi UU, Peraturan Pemerintah, Peraturan Presiden dan Peraturan Menteri tersebut, Dinas Pertanian Kota Denpasar telah bekerjasama dengan Fakultas Pertanian Universitas Udayana memetakan merekomendasikan sawah subak yang tergolong sangat direkomendasikan, direkomendasikan da, rekomendasi bersyarat dan tidak direkomendasikan untuk LP2B (Lanya et al., 2019). Subak Sembung yang direkomendasikan sebagai subak sangat direkomendasikan hanya berupa peta lokasi dan luasannya, belum memiliki data dan informasi sumber daya subak, yaitu: sumber daya lahan (SDL), sumber daya buatan (SDB), sumber daya manusia (SDM), sumber daya pertanian (SDP), peta kepemilikan lahan, potensi agrowisata dan juga fasilitas penunjang sarana prasarana yang sesuai dengan peraturan tersebut.

LP2B perlu didukung oleh data dan informasi sesuai dengan Peraturan Pemerintah (PP) No 25 tahun 2012 tentang Sistim Informasi LP2B, seperti database yang berbasis geospasial, dengan menggunakan teknologi remote sensing LP2B. Database LP2B, minimal memuat tentang fisik alamiah, fisik buatan, kondisi sumber daya manusia, status kepemilikan, luas dan lokasi lahan, dan jenis komoditas. Kawasan agroekowisata sebagaimana yang tercantum dalam PP No 110 Tahun 2015, harus memiliki database berupa nilai sapta nawa pesona dan juga fasilitas penunjang (Menteri Pariwisata Republik Indoensia, 2017).

Penelitian Hutauruk et al. (2016) dan Suarjaya et al. (2017) telah menggunakan teknonologi remote sensing dan 
Geographics Information System (GIS) untuk menyusun database sumber daya pertanian. Namun demikian database yang terintegrasi antara pertanian dengan pariwisata perlu dipublikasikan, khususnya untuk Subak Sembung. Berdasarkan permasalahan di atas maka penelitian ini berjudul "Aplikasi Remote Sensing dan Geographics Information System untuk Penyusunan Database LP2B dan Agrowista di Subak Sembung Kecamatan Denpasar Utara" sangat diperlukan. Tujuan penelitian ini untuk menyusun database Subak Sembung berbasis geospasial yang direkomendasikan sebagai LP2B. Meliputi inventarisasi dan deskripsi data SDL, SDB, SDP, SDM dan kepemilikan lahan, serta identifikasi dan evaluasi agroekowisata Subak Sembung.

\section{BAHAN DAN METODE}

Penelitian ini dilaksanakan pada November 2019 hingga April 2020. Lokasi penelitian di Subak Sembung Kelurahan Peguyangan Kecamatan Denpasar Utara, Kota Denpasar. Subak Sembung berbatasan langsung dengan wilayah Utara: Jl. Astrasura, Barat: Jl. Ahmad Yani, Timur : Desa Adat Peraupan dan Desa Peguyangan Kangin, dan Selatan: Jl. Bedahulu. Digitasi citra satelit dan analisis data dilaksanakan di Laboratorium Manajemen Sumber Daya Lahan, Konsentrasi Ilmu Tanah dan Lingkungan, $\quad$ Program Studi Agroekoteknologi, Fakultas Pertanian, Universitas Udayana.

Bahan yang digunakan dalam penelitian ini adalah Peta Rupa Bumi Indonesia (RBI) Kota Denpasar 1:25.000, Peta Jenis Tanah 1:500.000, Citra Satelit Resolusi Tinggi Worldview Kota Denpasar Tahun 2018, Peta Administrasi Kota Denpasar (RTRW Bappeda Denpasar 20112031), Peta Bidang Tanah ATR/BPN (www.atrbpn.go.id/Peta-Bidang-Tanah) sebagai acuan pada proses deleniasi batas kepemilikan lahan, Peta Subak Kota Denpasar Tahun 2019 (Lanya et al., 2019) untuk menentukan luas dan batas wilayah subak, kuisioner wawancara, dan Hardcopy citra Worldview Subak Sembung ukuran A0. Alat yang digunakan pada penelitian ini yaitu Laptop, software QGIS 2.18.0 (32 bit), software SAS Planet, software Microsoft Excel 2013 dan Microsoft Word 2013, software Locus GIS untuk mempermudah deleniasi batas kepemilikan lahan, Global Positioning System Handphone untuk menentukan titik lokasi sebenarnya, kamera telepon seluler sebagai alat pengambilan gambar di lapangan, 


\section{IMAS CAHYANINGTIYAS et al. Aplikasi Remote Sensing dan Geographics...}

peralatan tulis dan buku catatan untuk mencatat data yang diperoleh.

Penelitian menggunakan metode, yaitu: interpretasi citra satelit, analisis petapeta sumber daya lahan, survei lapang dan analisis data. Pelaksanaan penelitian ini meliputi 7 (tujuh) tahapan penelitian: studi pustaka, analisis citra satelit, pemetaan tentatif kepemilikan lahan, survei lapang, penyusunan database sumber daya subak, penyusunan database agrowisata dan evaluasi penilaian sarana prasarana. Studi pustaka merupakan metode pengumpulan data sekunder dari pustaka-pustaka berupa informasi yang berkaitan dengan daerah penelitian dan bahan penelitian, seperti referensi tentang kepemilikan lahan sawah, teori-teori tentang informasi geografis dan agrowisata, serta penggunaan aplikasi QGIS.

Analisis citra satelit, citra satelit yang digunakan yaitu citra Worldview Kota Denpasar tahun 2018 melalui aplikasi SAS Planet dan Qgis 2.18.0. Intepretasi lahan sawah dapat dicirikan dengan penampakan lempeng berpetak-petak, pola teratur dengan variasi warna hijau. Jalan dan jogging track dicirikan oleh garis lurus berwarna terang, saluran irigasi garis lurus berwarna gelap, galengan berupa garis yang berpetak petak di lahan sawah dan kepemilikan lahan sawah di cirikan sawah yang diapit oleh dua garis lurus (galengan), umumnya sejajar, dipotong oleh beberapa galengan yang melintang diantara garis sejajar. Pada setiap objek di beri atribut yang berbeda.

Pemetaan tentatif kepemilikan lahan, digitasi kepemilikan lahan yang mengacu pada peta bidang ATR/BPN. Peta di akses melalui web www.atrbpn.go.id/PetaBidang-Tanah dijadikan acuan dalam digitasi manual poligon kepemilikan lahan pada QGIS 2.18.0 kemudian dicetak dengan ukuran A0 ditunjukkan kepada pekaseh maupun petani subak. Survei lapang dilaksanakan dengan metode terstruktur, melalui wawancara atau komunikasi langsung kepada pekaseh dan petani. Data batas kepemilikan lahan sawah subak didapatkan dengan menunjukkan cetakan citra yang telah di deliniasi kepada pekaseh maupun anggota petani subak. Pengecekan batas kepemilikan di lapangan lahan dengan menggunakan aplikasi Locus GIS, selanjutnya dilakukan revisi batas kepemilikan melalui digitasi on screen.

Penyusunan database sumber daya subak, database sumber daya subak terdiri dari data spasial (poligon subak dan kepemilikan lahan) dan data atribut (SDL, SDB, SDP, SDM). Penyusunan dilakukan 
Agrotrop : Journal on Agriculture Science, 11 (1): 85 - 96 (2021)

menggunakan software QGIS 2.18.1 yang mengacu pada Pedoman dengan menginput citra dan tabel Microsoft penyelenggaraan Keputusan Menteri Excel dalam format CSV, kemudian Pariwisata, Pos dan Telekomunikasi Nomor dilakukan joint atribut data spasial dengan 5 Tahun 2017 dengan penilaian berupa data atribut menggunakan ID yang sama jenis fasilitas sarana prasarana, ada atau pada aplikasi QGIS 2.18. Penyusunan tidak adanya sarana prasarana dan juga database agrowisata, penyusunan database kualitas dari sarana prasarana yang ada. agrowisata berupa tabel nilai Sapta dan Nawa Pesona yang didapat dari hasil survei lapang. Pedoman penyelenggaraan tersebut berdasarkan Keputusan Menteri Pariwisata, Pos dan Telekomunikasi Nomor 5 Tahun 2017. Database tersebut berisi 7 (tujuh) nilai Sapta dan 2 (dua) Nawa Pesona dengan penilaian baik, sedang dan buruk. Data tersebut akan diinput ke dalam tabel Microsoft Excel dalam format CSV kemudian dilakukan joint atribut data spasial subak dan data hasil evaluasi sapta dan nawa pesona pada aplikasi QGIS 2.18. Evaluasi fasilitas penunjang sarana prasarana, penilaian sarana prasarana dilakukan dengan mengisi tabel quisioner

\section{HASIL DAN PEMBAHASAN}

Peta saluran irigasi, jogging track dan database sistem informasi LP2B pada Gambar 1a dan 1b. Kepemilikan lahan petani pemilik dan penggarap diperoleh langsung dari pekaseh dan anggota petani yang sedang berada dilahan sawah. Grafik persentase dan luas lahan petani pemilik penggarap disajikan pada Gambar 2 dan Gambar 3. Informasi agrowisata disajikan dalam bentuk zonasi dan database agrowisata berbasis geospasial pada Gambar 4a dan 4b. Ke empat gambar tersebut merupakan database yang harus dimiliki oleh LP2B. 
IMAS CAHYANINGTIYAS et al. Aplikasi Remote Sensing dan Geographics...

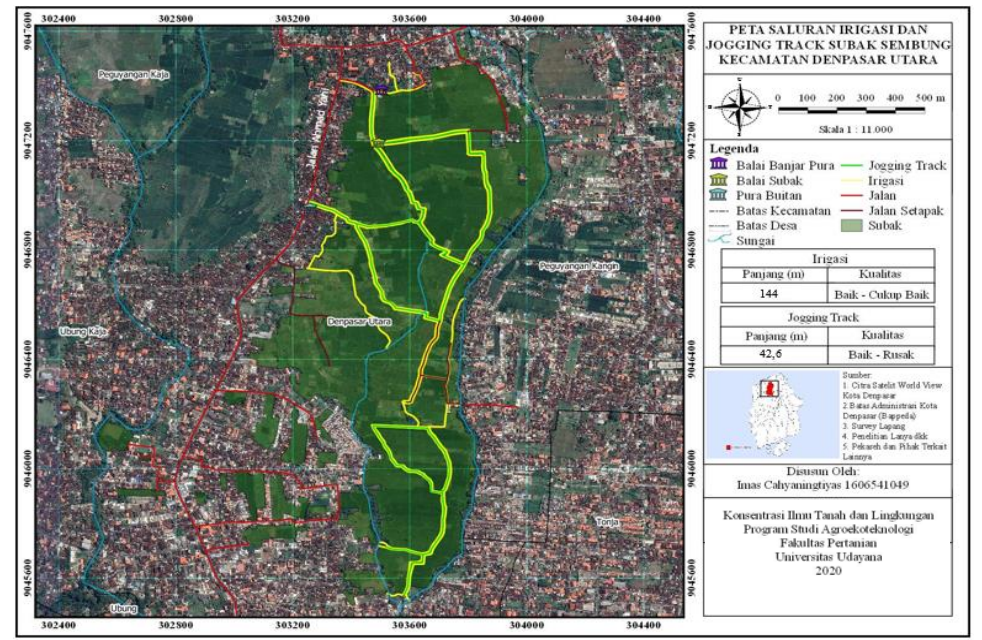

(a)

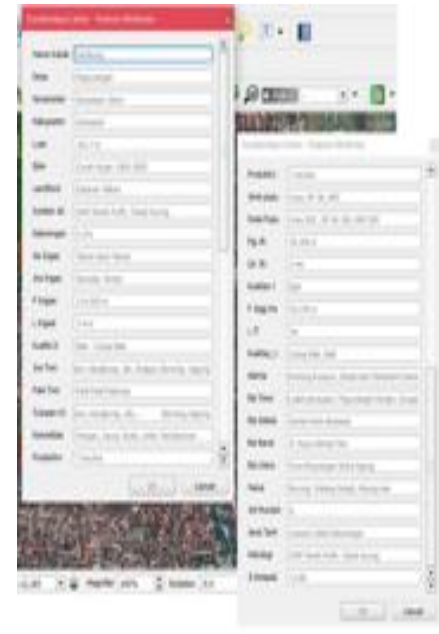

(b)

Gambar 1. (a) Peta Saluran Irigasi, Jogging Track, (b) Database Sistem Informasi LP2B

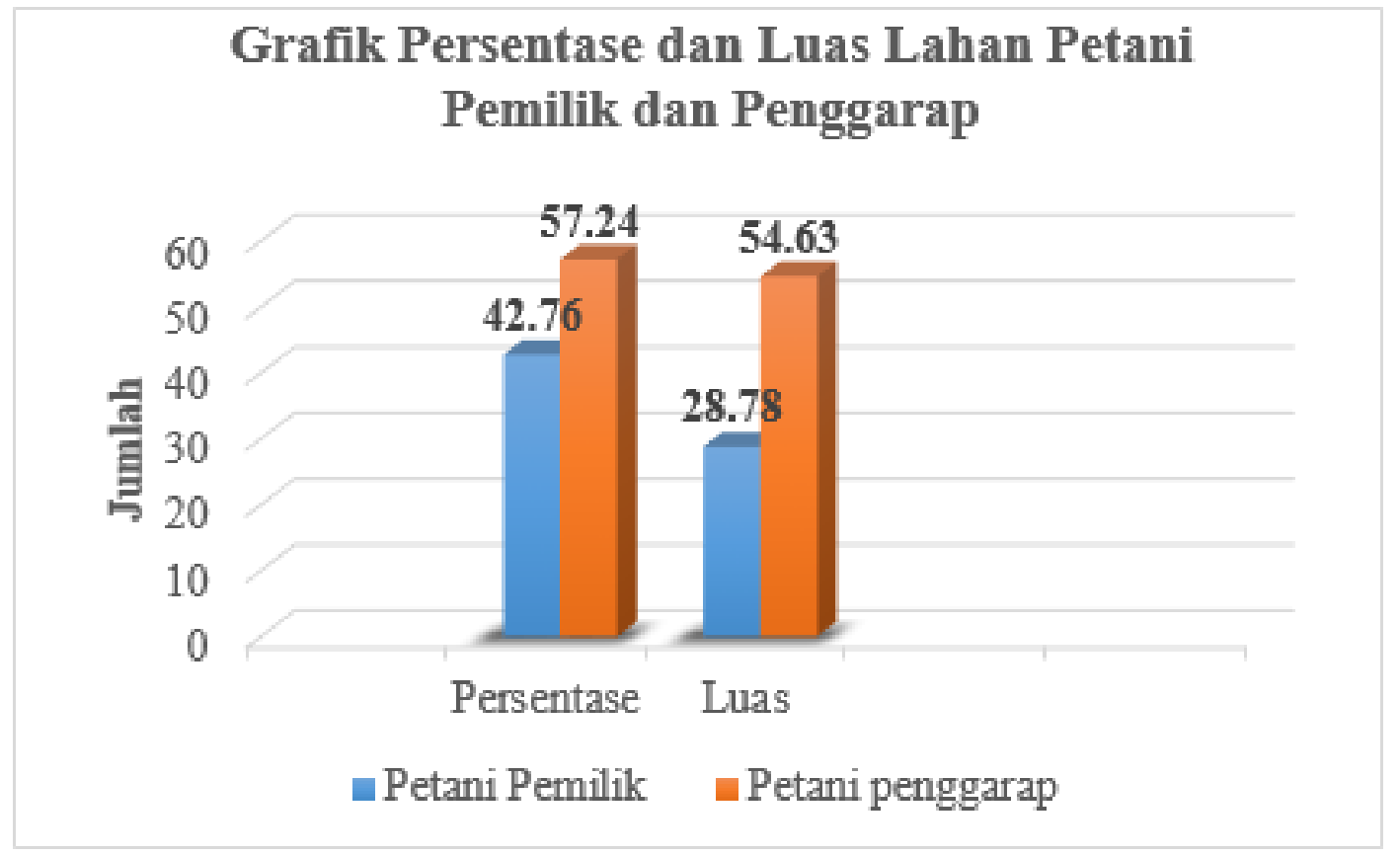

Gambar 2. Grafik Persentase dan Luas Petani di Subak Sembung (hasil analisis, 2020) 
Agrotrop : Journal on Agriculture Science, 11 (1): 85 - 96 (2021)

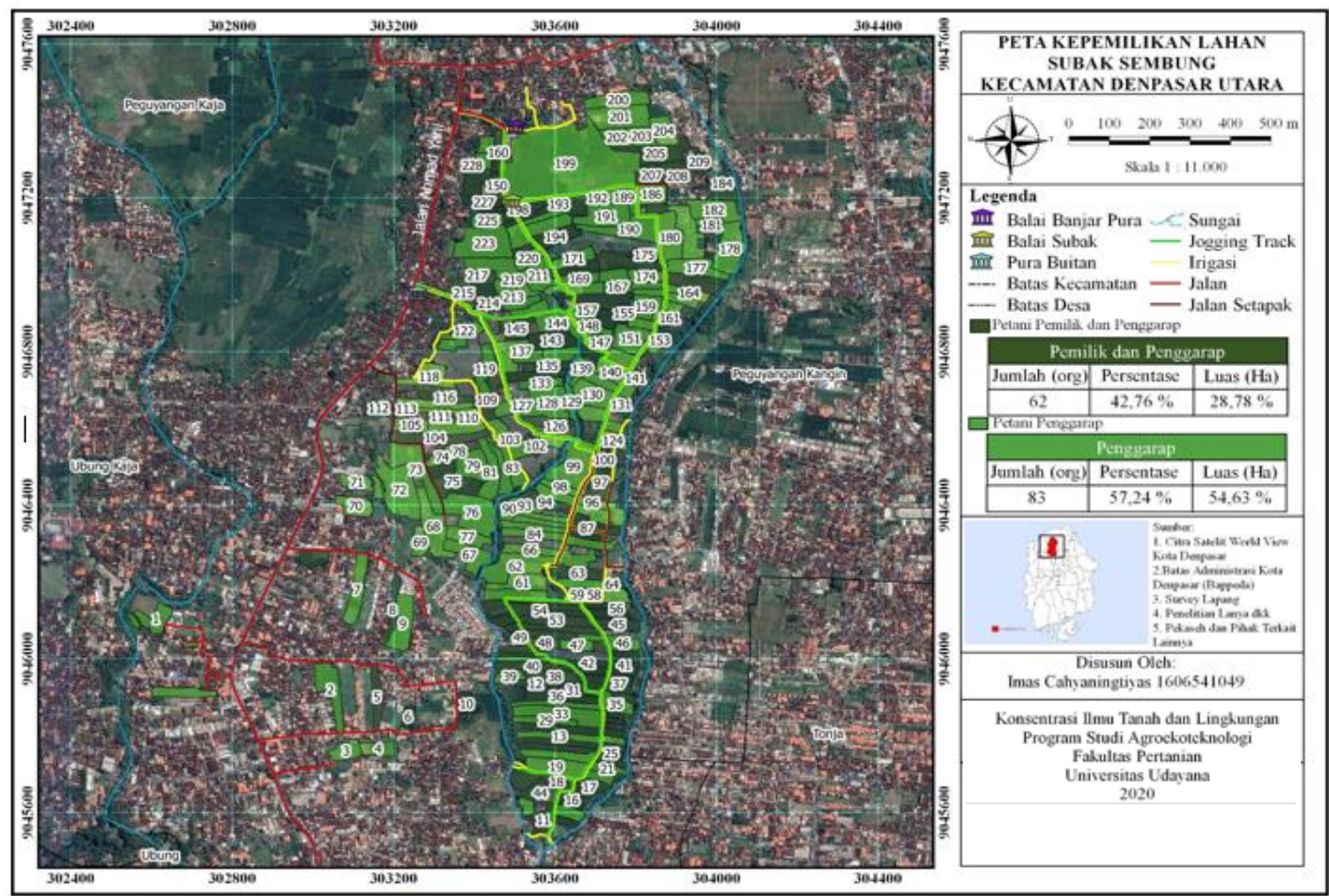

Gambar 3. Peta Kepemilikan Lahan Sawah di Subak Sembung Kecamatan Denpasar Utara

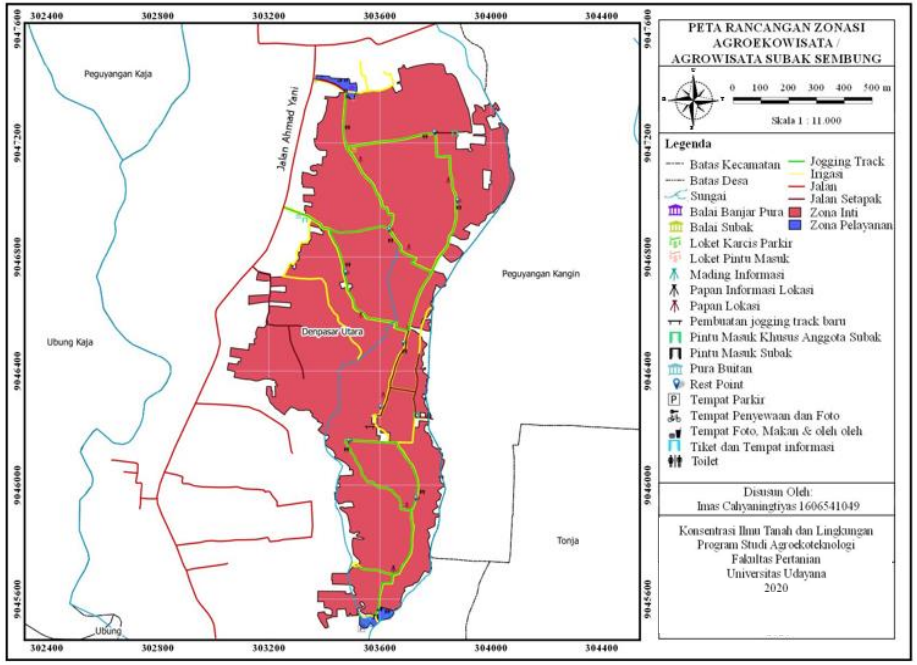

(a)

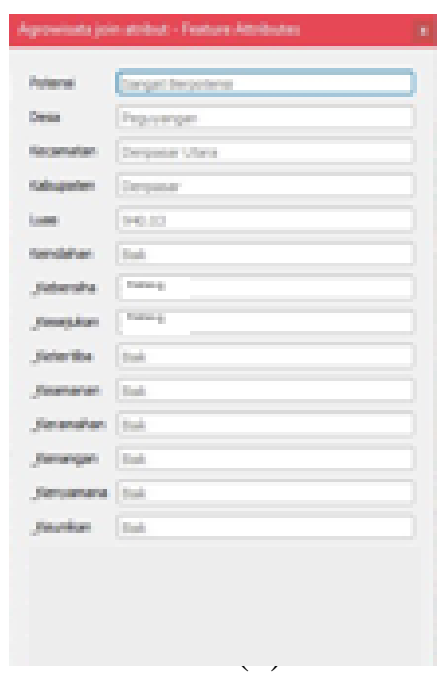

(b)

Gambar 4. (a) Peta Titik Rancangan Zonasi Agrowisata, (b) Database Agrowisata Berbasis Remote Sensing dan GIS Subak Sembung Kecamatan Denpasar Utara 


\section{IMAS CAHYANINGTIYAS et al. Aplikasi Remote Sensing dan Geographics...}

Teknologi remote sensing dan GIS yang digunakan dalam penelitian ini sangat memudahkan dalam membuat peta tematik: peta subak, peta irigasi, jogging track, peta kepemilikan lahan sawah serta peta potensi agrowisata. Hal ini disebabkan oleh bentuk dan ciri sawah pada citra satelit resolusi tinggi sangat mudah untuk mengelompokkan dan membatasi (digitasi) poligon sawah dengan penggunaan lainnya. Poligon kepemilikan lahan sawah diperoleh dengan bantuan peta bidang tanah ATR/BPN, sangat mudah diidentifikasi melalui petakan sawah yang sejajar satu sama lain pada citra satelit. Kombinasi kedua teknologi tersebut menghasilkan peta tematik berupa peta irigasi dan jogging track serta peta kepemilikan lahan sawah Subak Sembung: Ketiga peta tersebut akan memakan waktu lebih lama, bila dibuat hanya melalui survei lapang dan pemetaan secara manual, bila disbanding dengan menggunakan teknologi remotesensing dan GIS.

Informasi sumberdaya lahan (SDL) tercantum dalam Gambar 1b, menunjukkan bahwa potensi sumber daya Subak sembung tergolong baik, menggunakan teknologi remote sensing dan GIS. Peta pemilikan lahan sawah subak berbasis geospasial (Gambar 2 dan 3), maka database Subak
Sembung sudah sesuai dengan peraturan perundang-undangan dan layak ditetapkan sebagai LP2B. Total luas Subak Sembung 102,7 ha, terdiri dari lahan sawah seluas 83,41 ha, dan mengalami alih fungsi lahan sawah menjadi tanah kavling, restoran mina, balai subak, kolam ikan, dan kandang bebek seluas 19,29 ha. Subak Sembung terbagi menjadi delapan munduk dengan lima orang kelihan munduk: Curah hujan 1.500 - $2.000 \mathrm{~mm} /$ tahun, kemiringan lereng 3-8\%, landform dataran vulkan, berbahan induk tufa abu vulkanik: Jenis tanah pada lahan sawah subak tergolong Latosol Coklat Kekuningan dengan orde Inceptisol dan famili Typic Tropaquepts (Pusat Penelitian Tanah dan Agroklimatologi, 1996), sumber air Tukad Ayung dan DAM Tanah Putih. Kesesuaian lahan untuk padi sawah tergolong sangat sesuai (S1), ditunjang oleh air irigasi semi teknis, terasering, dan produktivitas 7 ton/ha. Karakteristik lahan menunjukkan bahwa kesesuaian lahannya tergolong S1 (Balitbang, 1993 dalam Mahubessy, 2014). SDP, komoditas yang diusahakan: tanaman pangan (padi, ubi, talas, jagung) dan hortikultura (kangkung, sawi, bawang, jeruk, pepaya, bunga pacar). Produktivitas padi sawah 7 ton/ha. Pola tanam pada umumnya berupa: padi-padi- 
palawija/hortikultura. Alsintan yang digunakan: traktor, alat pemotong rumput dan semprotan pembasmi hama. Pupuk yang digunakan urea $200 \mathrm{~kg} / \mathrm{ha}, \mathrm{SP}-36100$ kg/ha, dan NPK 200 kg/ha.

Gambar 2 menunjukkan bahwa umur petani berkisar 28-78 tahun. Petani yang memiliki umur lebih dari 50 tahun $(69 \%)$ lebih banyak dibandingkan dengan petani yang memiliki umur kurang dari 50 tahun (31\%). jumlah tertinggi sebanyak 12 petani $(8,3 \%)$, berusia 52 tahun. Total petani yang berada pada usia produktif (15-64 tahun) sebanyak 115 petani (79\%). Berdasarkan potensi SDL, SDP, SDB, dan SDM, Subak Sembung tergolong baik, oleh karena itu perlu dilestarikan. Faktor pembatas SDM dimana pemilik sawah umumnya petani penggarap yang berasal dari berbagai wilayah, bahkan dari Kabupaten Karangasem. Petani pemilik umumnya berumur lebih dari 60 tahun. Profil petani yang demikian menjadi salah satu faktor penghambat dalam pembangunan pertanian karena petani umur lebih dari 59 tahun sering dianggap kurang cekatan dan menolak teknologi baru (Sunar, 2012).

Berdasarkan Gambar 3 menunjukkan status kepemilikan lahan di Subak Sembung dibagi dua, yaitu pemilik dan penggarap. Total petani pemilik 62 orang $(42,76 \%)$ dengan luas lahan 28,78 ha, lebih kecil dibandingkan dengan petani penggarap 83 orang $(57,24 \%)$ dengan luas lahan garapan 54,63 ha. Petani pemilik yang lebih sedikit merupakan salah satu penyebab dari turunnya minat masyarakat terutama generasi muda terhadap sektor pertanian. Kepemilikan tanah pada umumnya berprofesi sebagai pegawai negeri, dokter, dosen dan juga pegawai bank yang tidak memungkinkan untuk bertani. Lokasi Subak Sembung berada di perkotaan sehingga banyak pekerjaan lain yang lebih menjanjikan. Berbagai usaha pemerintah telah dilakukan seperti memberi bantuan alsintan, membeli produk pertanian, dan juga percontohan usahatani. Namun sering tidak berkelanjutan, penyebab utama adalah petani sambilan dan penggarap ditambah masih banyak peluang pekerjaan di sektor non pertanian, seperti berdagang dan bekerja di sektor swasta yang lebih menjanjikan.

Fasilitas jogging track dan lokasi di pinggiran Kota Denpasar, merupakan daya tarik agroekowisata Subak Sembung. Ratarata jumlah pengunjung disetiap harinya 50 orang, meningkat pada hari sabtu, minggu, dan hari libur nasional. Berdasarkan Gambar 4a dan b memiliki lahan sangat berpotensi untuk dikembangkan sebagai 


\section{IMAS CAHYANINGTIYAS et al. Aplikasi Remote Sensing dan Geographics...}

kawasan agrowisata seluas 94,003 ha dan kurang berpotensi 8,679 ha. Lahan kurang berpotensi disebabkan letaknya yang berada di sekitar pemukiman warga dan terpisah dari hamparan luas sehingga akan sulit untuk dikelola. Agrowisata Subak Sembung sangat didukung dalam pengembagannya berdasarkan kondisi hidrologi, geologi, jenis tanah dan klimatologi. Ketersediaan air bersih, jenis tanah yang subur, suhu maksimal dan minimal yaitu $24{ }^{\circ} \mathrm{C}$ sampai dengan $\quad 31^{\circ} \mathrm{C} \quad$ sehingga sangat memungkinkan untuk pengembangan agrowisata. Hasil penelitian terkait nilai Sapta dan Nawa Pesona pada nilai keindahan, ketertiban, keamanan, keramahan, kenangan, kenyamanan, keunikan memiliki kategori baik, sedangkan nilai kebersihan, kesejukan memiliki kategori sedang.

Gambar 4a, menunjukkan kondisi fisik Subak sembung dilengkapi dengan hasil wawancara dengan pengunjung di lapang, menghasilkan, nilai Sapta dan Nawa Pesona, yaitu: keindahan, ketertiban, keamanan, keramahan, kenangan, kenyamanan, keunikan ke dalam kategori baik dan nilai kebersihan, kesejukan ke dalam kategori sedang. Oleh karena itu Subak Sembung mempunyai potensi daya tarik alam, buatan, dan daya tarik buatan, tergolong sedang. Potensi daya tarik juga dapat dinilai dari aspek aksesibilitas dan sarana/prasarana. Potensi daya tarik yang utama adalah keindahan pemandangan alam nuansa pedesaan, dilengkapi jogging track, sebagai sarana olah raga. Potensi agrowisatas cukup baik, terutama dari segi destinasi dan kelembagaan walaupun dari industri pariswisatanya dan promosi masih sangat kurang.

Subak Sembung terletak di pinggiran kota, jarak dari pusat Kota Denpasar 12 km dengan waktu tempuh 20-25 menit. Memiliki 2 (dua) pintu utama yang terletak di Jl. Ahmad Yani dan Jl. Bedahulu. Akses Subak Sembung dapat dilalui melewati berbagai penjuru mata angin dengan menggunakan kendaraan bus, mobil dan sepeda motor. Pintu masuk di Jl. Bedahulu hanya dapat dilalui oleh kendaraan motor, akses jalan yang kecil dan sempit. Minimnya arah petunjuk lokasi subak di lapangan belum tersedia, dapat diakses melalui Google Maps. Fasilitas penunjang yang berada di Subak Sembung berupa tempat ibadah, toilet, jogging track, kolam pancing, rumah makan, kursi taman, tempat sampah, dan juga warung. Fasilitas penunjang agrowisata perlu ditingkatkan dengan mengembangkan potensi yang ada seperti penambahan rest point yaitu sebagai 
tempat berisitrihat ataupun tempat untuk berfoto-foto dengan menggunakan konsep amati tiru dan modifikasi.

\section{SIMPULAN}

Database SDL, SDP, SDB, dan SDM tergolong baik, dilengkapi dengan peta kepemilikan lahan sawah berbasis geospasial. Hamparan sawah yang luas dan saluran irigasi baik, serta produksi tinggi ( 7 ton/ha), memenuhi persyaratan ditetapkan sebagai LP2B. Kepemilikan sawah, petani penggarap 83 orang $(57,24 \%)$ dengan luas 54,63 ha, petani pemilik 62 orang $(42,76$ $\%)$ luas garapan 28,78 ha. Rata-rata petani berpendidikan SD dan berumur 52 tahun. Nilai keindahan, ketertiban, keamanan, keramahan, kenangan, kenyamanan, keunikan ke dalam kategori baik dan nilai kebersihan, kesejukan ke dalam kategori sedang Lokasi dapat diakses dari berbagai arah menggunakan kendaraan bus, mobil dan motor. Memiliki sarana prasarana penunjang yang memudahkan pengunjung dalam memenuhi kebutuhannya.

\section{UCAPAN TERIMA KASIH}

Penulis ucapkan terimaksih kepada seluruh pihak yang telah memberikan bantuan pikiran dan tenaga. Ucapan terimakasih juga penulis sampaikan kepada
Prof. Dr. Ir Indayati Lanya, M.S. Sebagai pembimbing I dan Dr. Ir. Ni Made Trigunasih, M.P. sebagai pembimbing II. Kedua pembimbing telah banyak membimbing penulis dalam penyelesaian penelitian ini

\section{DAFTAR PUSTAKA}

Hutauruk, J. K. R., Lanya, I., \& Nuarsa, I. W. (2016). Sistem Informasi Lahan Subak Berbasis Penginderaan Jauh Dan Sistem Informasi Geografi Di Kota Denpasar. Jurnal Agroekoteknologi Tropika (Journal of Tropical Agroecotechnology), 5(3), 284-296.

Lanya, I., Trigunasih, N. M., Dibia, I. N., Ratna Adi., I. G. P., Sardiana, K., \& Arthagama, D. M. (2019). Digitasi Peta Pada Pemetaan Lahan Subak Kota Denpasar.

Mahubessy, R. C. (2014). Tingkat Kesesuaian Lahan Bagi Tanaman Padi Berdasarkan Faktor Iklim Dan Topografi Di Kabupaten Merauke. Agrologia, 3(2), 125-131. https://doi.org/10.30598/a.v3i2.253

Menteri Pariwisata Republik Indoensia, M. R. I. (2017). Peraturan Menteri Pariwisata No. 5 Tahun 2017 tentang Pedoman Destinasi Penyelenggaraan Pertemuan, Perjalanan Insentif, Konversi dan Pameran. https://pamongpraja.id/2017/11/17/pe raturan-menteri-nomor-5-tahun-2017tentang-pedoman-destinasipenyelenggaraan-pertemuanperjalanan-intensif-konvensi-danpameran/amp

Pemerintah Kota Denpasar, W. D. (2011). Peraturan Daerah No. 27 tahun 2011 Rencana Tata Ruang Wilayah Kota 


\section{IMAS CAHYANINGTIYAS et al. Aplikasi Remote Sensing dan Geographics...}

Denpasar 2011-2031. Lembaran

Daerah Kota Denpasat Tahun 3011

Nomor

https://jdih.denpasarkota.go.id

Peraturan Pemerintah Republik Indonesia, P. R. I. (2012). Peraturan Pemerintah No. 25 Tahun 2012 tentang Sistem Informasi LP2B. Lembaran Negara Republik Indonesia tahun 2012, No. 5283.

https://peratutaran.bpk.go.id/Home/D etail/5237/pp-no-25-tahun-2012

Peraturan Presiden Republik Indonesia, P. R. I. (2019). Peraturan Presiden No 59 tahun 2019 tentang Pengemda:lian Lahan sawah. Lembaran Negara Republik Indonesia tahun 2019 m Nomor 163. https://peraturan.bpk.go.id/Home/Det ails/120618/perpres-no-59-tahun2019

Pusat Penelitian Tanah dan Agroklimatologi, B. P. dan P. P. (1996). Daftar Peta Sumberdaya Lahan/Tanah Indonesia.

Suarjaya, D. G., Lanya, I., \& Ratna Adi, I. G. P. (2017). Aplikasi Remote Sensing dan Sig Untuk Pemetaan dan Informasi Sumberdaya Lahan Subak Sawah di Kecamatan Kuta dan Kuta Utara , Kabupaten Badung. Jurnal Agroekoteknologi Tropika (Journal of Tropical Agroecotechnology), 6(3), 239-248.

Sunar. (2012). Pengaruh Faktor Biografis (Usia, Masa Kerja, dan Gender) terhadap Produktivitas Karyawan. Forum Ilmiah, 9(1), 167-177. http://ejurnal.esaunggul.ac.id/index.p hp/Formil/article/viewFile/803/736

Undang-Undang Republik Indonesia, P. R. I. (2009). Undang-Undang Republik Indonesia No. 41 Tahun 2009 tentang Perlindungan Lahan Pertanian Pangan Berkelanjutan. 